\title{
The properties of biochars derived from different plant residue and different pyrolysis temperatures
}

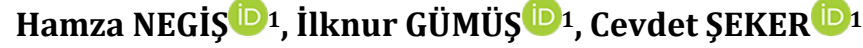 \\ ${ }^{1}$ Department of Soil Science and Plant Nutrition, Faculty of Agriculture, University of Selçuk, 42031 Konya \\ * This research has been I. International Agricultural Science Congress 09-12 May 2018 Van/Turkey is presented as poster presentation.
}

Alınış tarihi: 14 Mart 2019, Kabul tarihi: 1 Ekim 2019

Sorumlu yazar: İlknur GÜMÜȘ, e-posta: ersoy@selcuk.edu.tr

\begin{abstract}
By determining the degraded and limiting properties of the soil, producing solutions for the improvement of these properties will be able to provide sustainable and efficient use of soil. Especially, low organic matter content of soils causes many problems. Studies on increasing the organic matter content of soils by using various plant residues and organic fertilizers constituted the subject of many researches. However, in recent years, the use of biochar obtained by pyrolysis of various plant materials at high temperatures has become popular. With the use of biochar, both the characteristics of soil are improved, and greenhouse effect is reduced. Furthermore, it provides the production of various biofuels. The attributes of obtained biochar vary with pyrolysis material and temperature. The aim of this study was to produce biochar by pyrolyzing diverse plant residues in different temperature conditions and determine some physical and chemical properties of the biochar. For this purpose, sunflower stalk, sunflower head, corn stalk, corn cob and wheat straw were converted to biochar's at 300 ${ }^{\circ} \mathrm{C}, 400{ }^{\circ} \mathrm{C}, 500{ }^{\circ} \mathrm{C}$, and $600{ }^{\circ} \mathrm{C}$ temperatures. Biochar yield, surface area, $\mathrm{C} / \mathrm{N}$ ratio, $\mathrm{pH}$ and electrical conductivity (EC) values and water holding capacities of the experimental samples were determined. In the light of results, the highest surface area was found in sunflower stalk at $300{ }^{\circ} \mathrm{C}$, while the lowest surface area was detected as in wheat straw at $300{ }^{\circ} \mathrm{C}$. The $\mathrm{C} / \mathrm{N}$ ratios increased in all the samples except corn stalk and corn cob.
\end{abstract}

Key words: Biochar, plant residues, pyrolysis, temperature
Farkı bitki artıklarından ve değişik sıcaklıklarda
elde edilen biyokömürlerin özellikleri

Öz

Toprağın bozulmuş ve sınırlayıcı özelliklerini belirleyerek, bu özelliklerin iyileştirilmesi için çözümler üretmek, toprağın sürdürülebilir ve verimli kullanımını sağlayabilecektir. Özellikle, toprakların düşük organik madde içeriği birçok soruna neden olmaktadır. Çeşitli bitki kalıntıları ve organik gübreler kullanılarak topraktaki organik madde içeriğinin artırılmasına yönelik çalışmalar birçok araştırmaya konu olmuştur. Bununla birlikte, son yıllarda, çeşitli bitki materyallerinin yüksek sıcaklıklarda pirolizi ile elde edilen biyokömür kullanımı popüler hale gelmiştir. Biyokömür kullanımı ile hem toprağın özellikleri iyileștirilir hem de sera etkisi azaltılır. Bunların yanı sıra çeşitli biyoyakıtların üretimini sağlar. Elde edilen biyokömürün özellikleri piroliz materyali ve sıcaklık ile değişir. $\mathrm{Bu}$ çalışmanın amacı, farklı sıcaklık koşullarında farklı bitki artıklarının pirolize edilerek biyokömür üretilmesi ve elde edilen biyokömürlerin bazı fiziksel ve kimyasal özelliklerinin belirlenmesidir. Bu amaçla ayçiçeği sapı, ayçiçeği başı, mısır sapı, mısır koçanı ve buğday samanı, $300^{\circ} \mathrm{C}, \quad 400^{\circ} \mathrm{C}, \quad 500^{\circ} \mathrm{C}$ ve $600^{\circ} \mathrm{C}$ sicaklıklarinda biyokömüre dönüştürülmüştür. Kullanılan materyallerin biyokömür verimi, yüzey alanı, C/N oranı, pH ve EC değerleri ve su tutma kapasiteleri belirlenmiştir. Sonuçlar ışığında en yüksek yüzey alanı $300{ }^{\circ} \mathrm{C}$ 'de ayçiçeği sapında bulunurken, en düşük yüzey alanı $300{ }^{\circ} \mathrm{C}$ 'de buğday samanı olarak 
tespit edilmiştir. Mısır sapı ve mısır koçanı hariç tüm örneklerde $\mathrm{C} / \mathrm{N}$ oranları artmıştır.

Anahtar kelimeler: Biyokömür, bitki artıkları, piroliz, sıcaklık

\section{Introduction}

Biochar is the transformation product of biomass that occurs as a result of a thermochemical transformation in the presence of oxygen or in an oxygen-free environment. It is a material rich in organic carbon, which is obtained by heating a variety of organic matter such as wood, manure or leaves in a closed environment of low oxygen or an oxygen-free environment. The thermal decomposetion of organic matter with limited oxygen occurs at relatively low temperatures $\left(<700{ }^{\circ} \mathrm{C}\right)$. Biochar has received an increasing interest with the popularity of the need for soil regulator on a global level and also of the idea to use the soil as a carbon sink Lehmann et al. (2006). Biochars, with increasing use as soil and ecological regulator in recent years, when used together with organic and inorganic fertilizers as a soil conditioner, increases the soil aeration, product fertility, availability of plant nutrients, nutrient retention, and regulates soil $\mathrm{pH}$ and increases cation exchange capacity (CEC) by improving the physical properties of soil Lehmann et al. (2006); Novak et al. (2009); Song et al. (2014). The use of biochar in agricultural areas results in a slower decomposition of the organic carbon in the soil and an increase in the amount of organic matter in the soil; also, it has been reported that it helps to prevent global warming by reducing various greenhouse gas emissions such as $\mathrm{CO}_{2}$ and $\mathrm{N}_{2} \mathrm{O}$ and can cause improvements in soil properties. With these features, biochars with both environmental healing effects and the soil regulating characteristics in crop production are considered to be state-of-the-art materials used to recycle different types of organic waste which cannot be used in any other way. The aim of this study was to produce biochar from different plant residues in different temperature conditions via pyrolysis process and determine some physical and chemical properties of the biochar.

\section{Materials and Methods}

In this study, biochar was produced by the pyrolysis of 5 different plant materials (wheat stalks, corn cobs and stalks, sunflower tray, sunflower, corn stalk) under different temperature conditions (300 ${ }^{\circ} \mathrm{C}, 400{ }^{\circ} \mathrm{C}, 500{ }^{\circ} \mathrm{C}$ and $600{ }^{\circ} \mathrm{C}$ ). The materials collected from Konya region were first oven-dried at $70{ }^{\circ} \mathrm{C}$. Before beginning the process of pyrolysis, plant materials are chopped into smaller parts, wrapped in aluminum foil in an airtight manner, and burned for an hour (Figure 1).

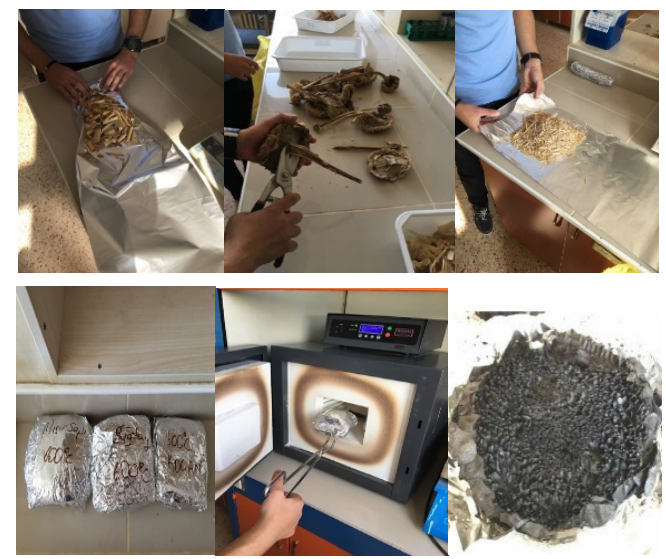

Figure 1. Preparation of samples

The conversion rates of the resulting products into biochar were calculated as a percentage, and the surface area (Figure 2), $\mathrm{C} / \mathrm{N}$ ratio, according to Wright and Bailey, (2001) pH and electrical conductivity, according to Gugino et al. (2009) and water holding capacity are examined.

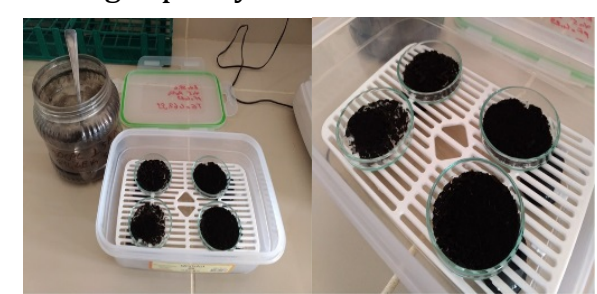

Figure 2. Surface area measurements

The results were analyzed using one-way ANOVA in Minitab software version 9 (State College, USA). All data were expressed as a mean of the three replicates. To identify significant differences between means of samples, Tukey's Multiple Range Test with a confidence interval set at 95\% was carried out Minitab (1995).

\section{Results and Discussion}

The inspected properties of the biochar made from 5 different plant materials are given in Table 1. Based on the burning temperatures (Figure 3), the surface areas of the Biochar's made from sunflower stalk and the sunflower head at $300{ }^{\circ} \mathrm{C}$, surface areas of those one made from corn stalk at $400{ }^{\circ} \mathrm{C}$ and those made from wheat straw at $500{ }^{\circ} \mathrm{C}$ and corn cob at $600{ }^{\circ} \mathrm{C}$ were found to be the highest. The value of surface area of biochar produced from different 
agricultural materials changes between 210 (sunflower stalk $300{ }^{\circ} \mathrm{C}$ ) and $102 \mathrm{~m}^{2} \mathrm{~g}^{-1}$ (wheat straw $400{ }^{\circ} \mathrm{C}$ ). Surface area value is one of the important physical properties that enable interaction between biochar and soil. Novak et al. (2009) stated in their study that the surface area of biochar made from peanut hulls, pecan shells, poultry litter and switchgrass at $250-750{ }^{\circ} \mathrm{C}$ varied between 0.40-222 $\mathrm{m}^{2} \mathrm{~g}^{-1}$. Spokas and Reicosky (2009) indicated that the value of surface area of 16 biochar types obtained in the different temperature (415-850 ${ }^{\circ} \mathrm{C}$ ) varied between 0.1- $286 \mathrm{~m}^{2} \mathrm{~g}^{-1}$ and differences in surface area of biochar was dependent on used material and temperature. Glaser et al. (2002) reported that biochar produced at a high temperature represent tremendous charge densities. Additionally, Downie et al. (2009) pointed out that the surface area of biochar increases with increasing in pyrolysis temperature. The resulting biochars' $\mathrm{C} / \mathrm{N}$ rates are with the lowest rates of $41 \%$ in sunflower head stalk $\left(600{ }^{\circ} \mathrm{C}\right)$ and with the highest $\mathrm{C} / \mathrm{N}$ ratio of $180 \%$ obtained in wheat straw $\left(300^{\circ} \mathrm{C}\right)$. The values of $\mathrm{C} / \mathrm{N}$ ratio varied depending on the material from which the biochar was obtained and the temperature. Bayram (2015) indicated that the $\mathrm{C} / \mathrm{N}$ ratio of biochar produced from 22 different materials varies between 42.62 and 362.18. The high carbon content causes the biochar applied to the soil to remain intact for many years Lehmann et al. (2006); Brewer (2012).

Table 1. Different plant residue and different pyrolysis temperatures mean physical and chemical attributes of biochar

\begin{tabular}{|c|c|c|c|c|c|c|}
\hline Raw material & $\begin{array}{c}\text { Temperature } \\
\left({ }^{\circ} \mathrm{C}\right)\end{array}$ & $\begin{array}{c}\text { Surface area } \\
\left(\mathrm{m}^{2} \mathrm{~g}^{-1}\right)\end{array}$ & $\mathrm{C} / \mathrm{N}(\%)$ & $\mathrm{pH}$ & $\mathrm{EC}\left(\mathrm{dS} \mathrm{m}{ }^{-1}\right)$ & $\begin{array}{c}\text { Water holding } \\
\text { capacity (\%) }\end{array}$ \\
\hline \multirow{4}{*}{ Sunflower stalk } & 300 & $210^{A}$ & $55^{J}$ & $11.05^{\mathrm{E}}$ & 17.23 & $520^{\mathrm{A}}$ \\
\hline & 400 & $166^{\mathrm{G}}$ & $74^{\mathrm{H}}$ & $10.87^{\mathrm{F}}$ & - & $390^{C}$ \\
\hline & 500 & 137J & $87 \mathrm{~F}$ & $10.58^{\mathrm{H}}$ & - & $340^{\mathrm{EF}}$ \\
\hline & 600 & $130^{\mathrm{K}}$ & $80^{G}$ & $11.23^{\mathrm{D}}$ & 9.17 & $340^{\mathrm{F}}$ \\
\hline \multirow{4}{*}{ Sunflower head } & 300 & $190^{\mathrm{C}}$ & $50^{\mathrm{K}}$ & $11.38^{\mathrm{C}}$ & 12.03 & $190^{\mathrm{N}}$ \\
\hline & 400 & $177^{\mathrm{EF}}$ & $83^{G}$ & $11.63^{\mathrm{B}}$ & - & $250^{J}$ \\
\hline & 500 & $154^{\mathrm{H}}$ & $45^{\mathrm{L}}$ & $10.75^{\mathrm{G}}$ & - & $196^{\mathrm{M}}$ \\
\hline & 600 & $145^{I}$ & $41^{\mathrm{M}}$ & $12.47^{\mathrm{A}}$ & 6.18 & $196^{\mathrm{M}}$ \\
\hline \multirow{4}{*}{ Corn stalk } & 300 & $198^{\mathrm{B}}$ & $62^{\mathrm{I}}$ & $6.81^{\mathrm{P}}$ & 2.46 & $520^{\mathrm{A}}$ \\
\hline & 400 & $202^{\mathrm{B}}$ & $54 \mathrm{~J}$ & $8.95^{\circ}$ & 3.38 & $391^{\mathrm{C}}$ \\
\hline & 500 & $191^{\mathrm{C}}$ & $43^{\mathrm{LM}}$ & $10.55^{\mathrm{H}}$ & 4.13 & $344^{\mathrm{E}}$ \\
\hline & 600 & $146^{\mathrm{I}}$ & $43^{\mathrm{LM}}$ & $10.53^{\mathrm{H}}$ & 4.20 & $341^{\mathrm{EF}}$ \\
\hline \multirow{4}{*}{ Corn cob } & 300 & $180^{\mathrm{D}}$ & $87^{F}$ & $10.30^{\mathrm{J}}$ & 1.83 & $266^{I}$ \\
\hline & 400 & $170^{\mathrm{F}}$ & $88^{\mathrm{F}}$ & $10.72^{\mathrm{G}}$ & 1.22 & $222^{\mathrm{K}}$ \\
\hline & 500 & $178^{\mathrm{DE}}$ & $88^{\mathrm{EF}}$ & $10.14^{\mathrm{K}}$ & 1.81 & $207^{\mathrm{L}}$ \\
\hline & 600 & $190^{\mathrm{C}}$ & $90^{\mathrm{E}}$ & $10.41^{\mathrm{I}}$ & 1.96 & $184^{\circ}$ \\
\hline \multirow{4}{*}{ Wheat straw } & 300 & $110^{\mathrm{LM}}$ & $180^{\mathrm{A}}$ & $10.08^{\mathrm{K}}$ & - & $468^{\mathrm{B}}$ \\
\hline & 400 & $102^{\mathrm{N}}$ & $110^{\mathrm{C}}$ & $9.54^{\mathrm{N}}$ & - & $375^{\mathrm{D}}$ \\
\hline & 500 & $115^{\mathrm{L}}$ & $120^{\mathrm{B}}$ & $9.62^{\mathrm{M}}$ & - & $333^{\mathrm{G}}$ \\
\hline & 600 & $108^{\mathrm{MN}}$ & $100^{\mathrm{D}}$ & $9.75^{\mathrm{L}}$ & - & $323^{\mathrm{H}}$ \\
\hline
\end{tabular}

*- no measurement

Biochar's pH contents varied between 12.47 and 6.81. The high $\mathrm{pH}$ value of biochar is due to accumulated basic cations within biochar (Chan and $\mathrm{Xu}, 2009)$. Probably due to the relative concentration of non-pyrolyzed inorganic elements that are found within original feedstocks, the $\mathrm{pH}$ value of biochars scaled up with temperature Novak et al. (2009). Jindo et al. (2014) indicated that the $\mathrm{pH}$ value of biochar made from apple tree branch, oak tree, rice husk, and rice straw at $400-800{ }^{\circ} \mathrm{C}$ ranged from 6.43 to 10.47. All biochars' salinity was higher and had EC ranged from 1.22 (corn cob, $400{ }^{\circ} \mathrm{C}$ ) to $17.23 \mathrm{dS} \mathrm{m}^{-1}$ (sunflower stalk at $300{ }^{\circ} \mathrm{C}$ ). Overall, EC values seemed to increase with pyrogenic temperature. This is in line with Kloss et al. (2012), who similarly revealed results for biochars produced at 400 and $525{ }^{\circ} \mathrm{C}$. When water retention capacity which is an important feature of biochars was examined, it was seen that all samples had high water retention capacities due to their high surface areas. The water holding capacity of biochar produced from different agricultural materials changed between 190 (sunflower head $300{ }^{\circ} \mathrm{C}$ ) and $520 \%$ (sunflower stalk $300{ }^{\circ} \mathrm{C}$ ). The porosity and surface area show the most critical physical properties of biochar for improving soil properties, namely soil adsorption ability and water holding capacity Kalderis et al. (2008). The study of the properties of the resulting biochar varied by the plant varieties, plant parts and incinerator temperatures used for producing 
biochars. It has been observed that one of the examined properties, the surface area increases after the burning process, but decreased by temperature except for corn cob. When $\mathrm{C} / \mathrm{N}$ ratios were examined, increasing or stable rates have been observed depending on the temperature $\mathrm{pH}$ and EC values and could not be read due to the fact that some biochar materials have high surface area and high water-holding capacity. When $\mathrm{pH}$ values were examined, it has been found that the biochars have high $\mathrm{pH}$ and should be used as the regulator of soils with low $\mathrm{pH}$. The first priority is to use the available water potential in arid and semi-arid climate areas with the highest efficiency. It is seen that the obtained biochar has high water retention capacities. For this reason, it is recommended to use biochar for more efficient use of the water and more storage in the soil found in arid and semi-arid climatic zones.
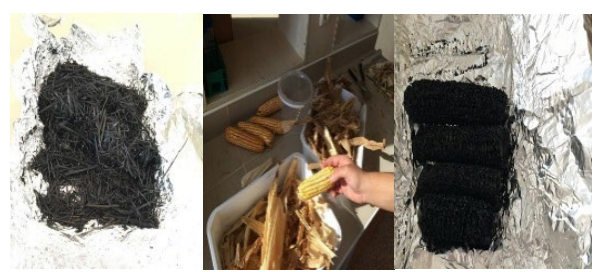

Figure 3. Corn cob and wheat have been seeing after from burning

\section{Conclusions}

As a result, biomass energy source could be used, when transformed into Biochar, as a versatile and advantageous material in many areas such as energy storage, and removal of organic and inorganic contaminants. The most important point in the use of biomass energy is that it should not be used as raw material of the foods used in human nutrition. Wastes should be used instead. The recycling of biomass waste, mostly left to decay, and its transformation into high value-added products also contributes to the removal of pollutants.

\section{References}

Bayram, Ö., 2015. Farklı tarımsal atıklardan üretilen biyoçarların çeşitli fiziksel ve kimyasal özelliklerinin belirlenmesi. Gaziosmanpaşa Üniv Fen Bil. Ens, Yüksek Lisans Tezi, Tokat, 46s.

Brewer, C.E., Schmidt-Rohr, K., Satrio, J.A., Brown, R.C., 2009. Characterization of biochar from fast pyrolysis and gasification systems. Environ Prog Sustain Energy 28: 386-396.

Chan, K., Xu, Z., 2009. Biochar: Nutrient properties and their enhancement. Earthscan, London.
Downie, A., Crosky, A., Munroe, P., 2009. Physical properties of biochar. In: Lehmann, J., Joseph, S. Biochar for Environmental Management Science and Technology. Earthscan, London, pp. 227-249.

Glaser, B., Lehmann, J., Zech, W., 2002. Ameliorating physical and chemical properties of highly weathered soils in the tropics with charcoal. Biology and Fertility of Soils 35: (4) 219-230.

Gugino, B., Idowu, O., Schindelbeck, R., Van Es, H., MoebiusClune, B., Wolfe, D., Thies, J., Abawi, G., 2009. Cornell soil health assessment training manual. Edition 2.0, Cornell University, Geneva, NY.

Jindo, K., Mizumoto, H., Sawada, Y., Sanchez-Monedero, M.A., Sonoki, T., 2014. Physical and chemical characterization of biochars derived from different agricultural residues. Biogeosci 11: 6613-6621.

Kalderis, D., Kotti, M. S., Méndez, A., and Gascó, G., 2014. Characterization of hydrochars produced by hydrothermal carbonization of rice husk. Solid Earth, 5: 477-483.

Kloss, S., Zehetner, F., Dellantonio, A., Hamid, R., Ottner, F., Liedtke, V., Schwanninger, M., Gerzabek, M.H., Soja, G., 2012. Characterization of slow pyrolysis biochars. J. Environ. Qual. 41: 990-1000.

Lehmann, J., Gaunt, J. ve Rondon, M., 2006. Biochar sequestration in terrestrial ecosystems-a review. Mitigation and Adaptation Strategies for Global Change, 11 (2): 403-427.

Minitab: Minitab reference manual (Release 7.1), Minitab Inc., State Coll PA, 16801, USA, 1995.

Novak, J. M., Busscher, W. J., Laird, D. L., Ahmedna, M., Watts, D. W., Niandou, M. A., 2009. Impact of biochar amendment on fertility of a southeastern coastal plain soil. Soil Science, 174 (2): 105-112.

Song, Y., Zhang, X., Ma, B., Chang, S. X., Gong, J., 2014. Biochar addition affected the dynamics of ammonia oxidizers and nitrification in microcosms of a coastal alkaline soil. Biology and Fertility of Soils, 50 (2): 321-332.

Spokas, K.A., Reicosky, D.C., 2009. Impacts of sixteen different biochars on soilgreen gas production. Annals of Environmental Science 3: 179-193.

Wright, A. F., Bailey, J. S., 2001. Organic carbon, total carbon, and total nitrogen determinations in soils of variable calcium carbonate contents using a Leco CN-2000 dry combustion analyzer. Communications in Soil Science and Plant Analysis, 32 (19-20): 3243-3258. 